\title{
AN ANALYSIS OF THE ENERGY RESOURCES IN THE REPUBLIC OF MOLDOVA
}

\author{
Gheorghe STAVARACHE, Valerian NOVAC, Sorin CIORTAN, Eugen RUSU
}

“Dunarea de Jos" University of Galati, Department of Mechanical Engineering, 111 Domneasca, Galati, Romania

\begin{abstract}
The paper presents an analysis of renewable energy available in the Republic of Moldova. Because of geographic localization, there is no possibility to use wave energy so, the wind, solar, rivers and biomass sources are taken into account. After a short presentation of benefits and drawbacks of each energy source, an estimation for the Republic of Moldova is performed. The analysis results pointed out that the wind energy is the most used type and there is a lot of information about the wind speed values over the whole country area.
\end{abstract}

Keywords: renewable energy, resources analysis, Republic of Moldova

\section{INTRODUCTION}

In the Republic of Moldova, the renewable energy sector is experiencing slow, but positive dynamics. In 2015, the ratio of renewable energy produced to final energy consumption exceeded the level of $15 \%$. The private sector is involved in the production of electricity based on the use of wind, solar and biogas. Although the use of these types of energy is expanding, their share in the total renewable energy is very small (about $0.5 \%$ in 2015).

\section{RENEWABLE ENERGY SOURCES}

While Europeans are already using the potential of renewable energy, in Moldova, its capacity has reached only $6 \%$ of the total energy used and it is expected to increase this figure to $20 \%$ in 2020 . But the constant increase in prices and the fear of possible loss of energy resources and the need to reduce the volume of greenhouse gases emitted in our country creates all the premises for the emergence of a new market - an alternative energy market.

The alternative energy market is already developing rapidly in Europe. Romania takes the first confident steps in this direction. Russia is quite cold about this problem, probably due to its traditional energy resources. As for Moldova, until recently, everything related to alternative energy was simply ignored. There were some statements, but, at the level of actions, everything was zero.

\section{THE WIND AND THE SUN OFFER UNLIMITED POSSIBILITIES.}

The lack of a market as such is compounded by the total ignorance regarding the priorities and stability of renewable energy systems as compared to traditional ones. Therefore, instead of the market, there is a clear field, which is not yet occupied by manufacturers and sellers of relevant technologies and facilities, but experts say there is a certain demand, but it still seems to. Hello, investors!

Convinced that the provision of energy resources guarantees the security of the state, Moldova is only beginning to take the first serious measures to replace the traditional energy sources. But due to the lack of information, even the bravest of business people who risk addressing this topic face an empty wall when it comes to the profitability of this market. Only in general terms, there are the advantages of using renewable energy sources known: biomass, solar, wind, hydro and geothermal. The annual technical potential of these sources (without geothermal) is 2.5 mil. TEP (tonne of oil equivalent).

So far, no one can determine how this volume is capable of covering the needs of the country. But some experts argue that if specialists learn to combine the high potential of existing green energy with existing high technologies, we will be able to independently set our own energy strategy, significantly reduce the annual costs of electricity and heat, and we balance the national economy with a few years, to increase the possibilities of public and private budgets and, like all European countries, to contribute to reducing greenhouse gas emissions. 


\section{RENEWABLE ENERGY USED TODAY}

We could use solar energy for three types of installations: for heating water, drying agricultural products and pumping water for small-scale irrigation. Valeriu Kazak, former director of the State Hydrometeorological Service of the Republic of Moldova, informed us that there are technological capabilities of recovery and re-use of methane by evaporation, as a result of decomposition, by anaerobic fermentation of solid waste, manure and wastewater, waste from wastewater treatment plants, because all of them are of organic origin (biomass). "In the industrial production of electricity using wind poles, we can use wind turbines with an average annual wind speed of $6 \mathrm{~m} / \mathrm{s}$ from the Soroca region and the Stefan-Voda region, as well as from the Codru region and the Tigheci village, Leova district. Republic of Moldova could use the hydraulic potential of the the Nistru, Prut and Raut for irrigation or industrial production in adjacent regions", reveals Valeriu Kazak the secret of the areas with the highest potential for using the conversion facilities. The most important sources of renewable energy are:

-wind energy,

- the energy of the sun,

- the energy of the rivers,

- biomass energy.

\section{SOLAR ENERGY}

Studies conducted in recent years [2] prove the existence of hundreds of small consumers of electricity dispersed territorially, for which the only rational solution is the one offered by the PV conversion of solar energy, among which: water pumping installations for small irrigation, water supply stations. Launch of hail missiles and small electricity consumers dispersed territorially. With the help of photovoltaic installations, the irrigation of small areas of 1 ha, 5 ha, 10 ha is foreseen. The total capacity of small irrigation is 36 thousand ha or $22 \%$ of the total irrigable area of about 160 thousand ha. As sources, 3,000 accumulations of water, lakes, etc. will be used, of which 411 are the most important [11].

In order to evaluate the number of potential consumers of photovoltaic electricity, the statistical data regarding the production of vegetables in the peasant households were analyzed. According to a sociological study, carried out in August 2001 by the non-governmental organization „National Federation AGRO inform" in collaboration with the Contact Center, about $23.5 \%$ of the peasant households from the questioned ones have as main activity the cultivation of vegetables. Thus, the actual number of consumers of water for irrigation can be 5 to 6 times higher. The daily electricity consumption of an antigen haul launcher is increasing and depends on extending the consumption to cover the modern needs related to the technical composition of the antigrain station and to improving the living conditions of the service personnel. At the same time, it is necessary to reduce the participation of the human factor in the photovoltaic system service and to increase the efficiency of the conversion of solar energy, conditions that require the automated orientation of the photovoltaic panel to the sun. These requirements were submitted by the AntiIndigenous Services of the Republic of Moldova. Also, the requirements submitted by the Antigrain Service in Romania, which intend to procure photovoltaic systems produced in the Republic of Moldova, have been taken into account [9].

Due to the need to connect the performance of photovoltaic systems for supplying antigrain stations to modern requirements, a photovoltaic system with self-orientation to the sun was developed, assembled and tested at the Technical University of Moldova (Fig. 1) [4].

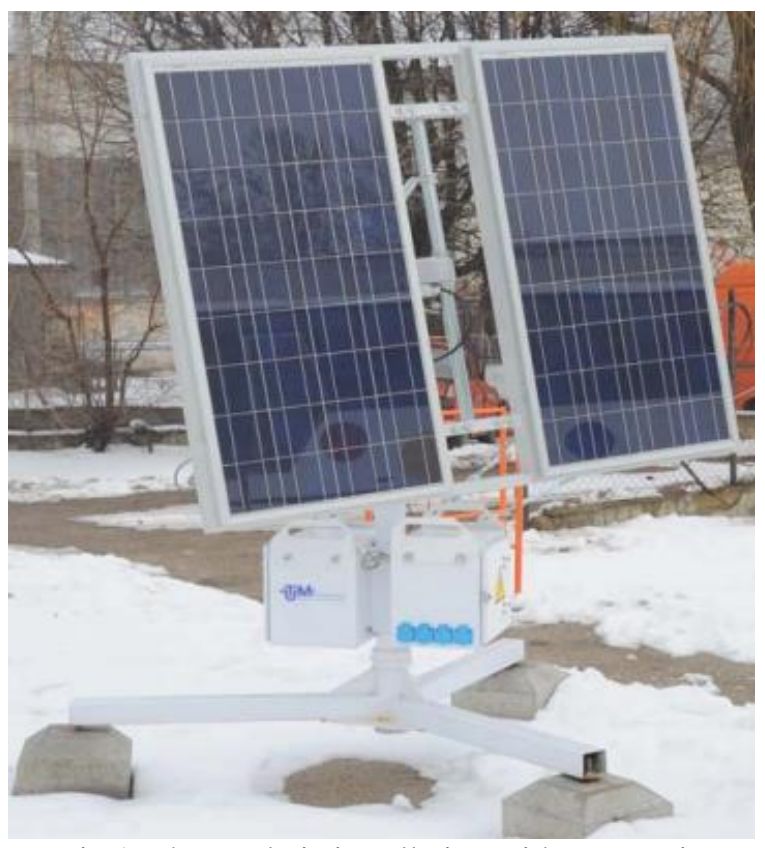

Fig.1. Photovoltaic installation with automatic orientation to sun for electricity supply of hail stations and water pumping [4]

\section{POTENTIAL WIND ENERGY}

Given that Moldova is a country where agriculture is the priority branch of the national economy, in order to plant agricultural crops under appropriate conditions, it is necessary to know the spatial distribution for solar radiation, air temperature and atmospheric precipitation. For this reason, the research team from the Institute of Ecology and Geography of the Academy of Sciences of Moldova has developed the Digital Climate Atlas of the Republic of Moldova.

The map of the wind potential at a height of $70 \mathrm{~m}$ above the ground does not answer one of the main 
questions - what is the wind potential of the Republic of Moldova, either theoretically or technically, or of certain areas, regions? The cause is as follows: WAsP 2.1 software version and the computing capacity of the computers, used at the time, did not allow the discretization of large areas of land, for example, with a step of 50-100 m. The study authors calculated wind speed and density. at different points located at relatively large distances (a few $\mathrm{km}$ ), they then mapped (mapped) the assumption that speed and power density are constant. Also, we have not answered the question regarding wind power potential, in other words, wind capacity, in terms of electric power, which can be installed in any region. Knowing this indicator is important in making strategic decisions regarding the development of the renewable energy sector.

\section{GREAT RIVER ENERGY}

Hydroelectric energy is the most widespread and most mature application of renewable energy. About $16 \%$ of the world's electricity production was produced by hydroelectric plants in 2010 .

The Republic of Moldova does not have fossil fuel deposits, but in its territory such rivers flow as Nistru and Prut, a series of smaller rivers, which are of interest to be arranged. We cannot afford to talk about building high-power hydroelectric power stations, but it is possible to build low-power generating units, even on lower water courses. These will be of local importance and use, but which by their number, through the cumulative effect, will improve what we call "energy security".

Currently, in Moldova the hydroelectric power is produced by two hydroelectric plants: CHE Dubăsari, with an installed power of $48 \mathrm{MW}$ and CHE Costeşti - 16 MW. Several micro-hydroelectric plants were built by individual producers and economic agents. All small generating units are built on the basis of the dams of the existing accumulation lakes.

Micro-hydro plants come with a set of advantages, among which we could mention: -are suitable for small, decentralized tasks (light industry, private farms, rural community enterprises, etc.);

-distribution is carried out at low and medium voltages;

-short duration of building of the plant, -relatively small specific investment, -high efficiency, -reduced operating and maintenance expenses.

\section{BIOMASS ENERGY}

The term biomass describes a wide range of animal and plant waste. Literally, it means "biological material". Biomass is the oldest source of energy used by mankind. Its occurrence dates from the time of people's control of fire.

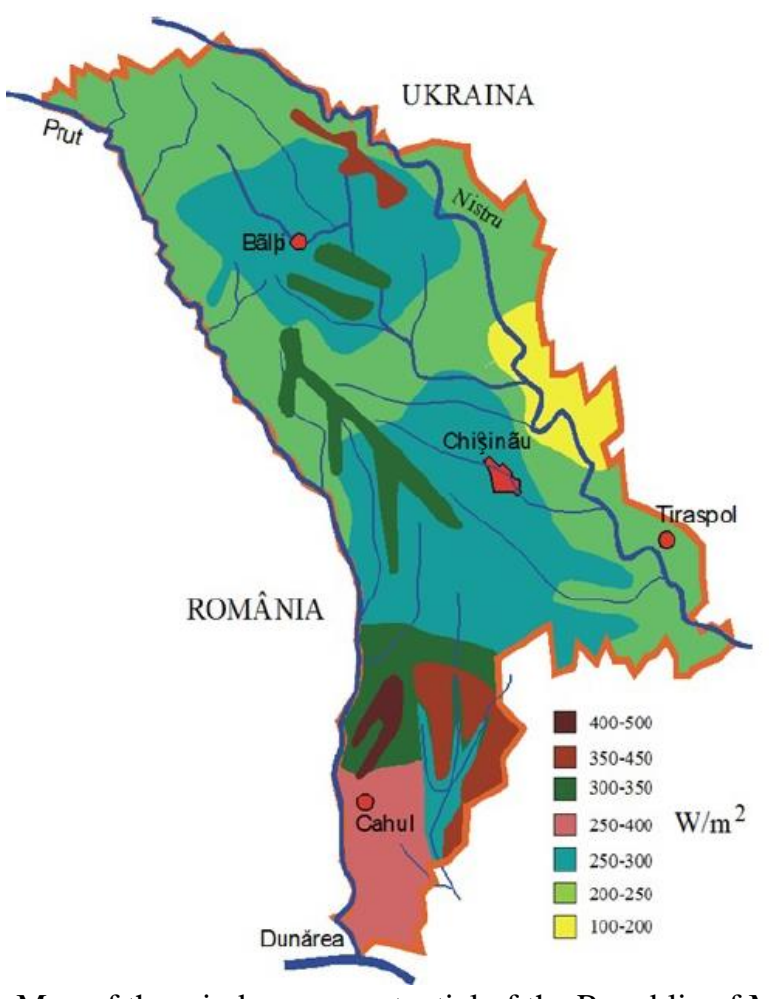

Fig. 2. Map of the wind energy potential of the Republic of Moldova, at a height of 70 meters from the ground [12] 
Types of biomass and fuel from this biomass are considered a renewable source of energy, because the energy contained in it is produced during photosynthesis, when plants convert the sun's radiant energy into hydrocarbons. Plant cultivation especially for biomass conversion is, in fact, a form of solar energy conservation.

During combustion, hydrocarbons produce heat, carbon dioxide $\left(\mathrm{CO}_{2}\right.$, so-called "greenhouse") and water. Carbon dioxide returns to the environment and participates in the biochemical cycle of carbon (the carbon cycle), contributing to the growth of other plants and the recovery of burned biomass. Thus, burning the biomass with the correct organization of the process does not lead to the additional pollution of the environment with carbon dioxide. The water returns to a natural ski jet (water cycle in nature). Heat can be used to generate electricity, as well as to meet other energy needs of mankind.

Some types of biomass - a tree, for example - can simply be burned to get energy from biomass. However, there are technologies that make it possible to obtain fuels liquids and gasses from wood and other biological materials. They can be used together (and possibly in the future and instead) with gasoline, diesel, methane and propane.

The main types of raw materials for producing biomass electricity include the following:

- herbaceous trees and plants,

- cereals and cereal bowl,

- aquatic and marine plants,

- manure and sewage.

\section{CONCLUSIONS}

1. Renewable energy is gaining more and more land worldwide. Renewables are already the second major source of electricity globally, but their use must be accelerated to meet long-term climate goals. As costs continue to fall, more and more grants are being made available for use.

2. Only $2 \%$ of the electricity consumed in the Republic of Moldova is obtained from renewable sources. This is because our country has a huge potential in terms of green energy sources. That is why it is necessary to study as widely as possible for the development of this segment.

3. At present, most information is only available for wind energy. Based on the wind power distribution map in Moldova, locations for wind farms can be chosen. In choosing the locations, the following should be taken into account:

- future urban plans,

- areas of strategic interest,

- the distance to the consumer,

- the region's infrastructure,

- the roughness of the terrain,

- airports nearby.

\section{REFERENCES}

[1] Ambros T. (1999), Surse regenerabile de energie, Chişinău: Tehnica-Info.

[2] Bostan I. et al. (2007), Sisteme de conversie a energiilor regenerabile, Chişinău: Tehnica-Info, Bons Offices.

[3] Bostan I. et al. (2011), Utilizarea surselor regenerabile de energie- eoliană, hidraulică şi solară, Academos, 4.

[4] Constantinov T., Răileanu V., Nedealcov M. (2005) Particularităţile distribuţiei spaţiale a radiatiei solare pe teritoriul Republicii Moldova sursă de energie renovabilă reală, Energetica Moldovei, Chişinău, AŞM, pp. 642-645.

[5] Constantinov T, Răileanu V., Nedealcov M, Crivova O. (2007) Evaluation du regime thermique du territoire de la République de Moldavie en utilisant le SIG. Lucrările Simpozionului „Sisteme Informaţionale Geografice", Analele Ştiinţifice ale Universităţii „Al. I. Cuza” Iaşi, Tom LIII, s. II c., Geografie, 13, Editura Universităţii „Al. I. Cuza” Iaşi, pp. 11-21.

[6] Constantinov T, Răileanu V., Crivova O. (2009) The identification of precipitation distribution's regional particularities using informational technologies. Bul Inst. Politec, Iaşi. Univ. Teh. „Gh. Asachi”, Iaşi, Tom LV, Fasc. 3, s Hidrotehnica, pp. 37-43.

[7] Constantinov T, Raileanu V, Nedealcov M, Crivova O. (2009) Spatial modelling of solar radiation components using Geographic Information Systems.

http://www.geomatica.uaic.ro/articole/NR.14_2009

[8] Rusu E. (2018) A 30-year projection of the future wind energy resources in the coastal environment of the Black Sea".

[9] Hotărîrea Guvernului RM nr. 1092 din 31.10.2000: $\mathrm{Cu}$ privire la utilizarea resurselor energetice regenerabile, Monitorul Oficial al RM nr.141-143/1201 din 09.11.2000.

[10] Bostan I., Dulgheru V., Sobor I., Bostan V., Sochireanu A. (2007) Sisteme de conversie a energiilor regenerabile, Editura „Tehnica-INFO”, Chișinău.

[11] Sobor I. (2008) Potenţialul energetic eolian al Republicii Moldova: modele, estimări, măsurări şi validări.

http://www.energyplus.utm.md/index.php/articles/33 -energia-eoliana-vantului/148-potentialul-energeticeolian-al-republicii-moldova-modele-estimarimasurari-si-validari

[12] Sobor I., Chiciuc A. Rachier V. (2017) Atlasul Resurselor Energetice al RM, UTM .

[13] *** Global Atlas for Renewable Energy, IRENA, 2014 , http://irena.org/DocumentDownloads/Publications/G A_Booklet_Web.pdf 
[14] Legea RM privind conversarea energiei $n r$. 1136-XIV din 13.07.2000, Monitorul Oficial al RM nr. $157-159 / 1183$ din 21.12.2000.

[15] Nikolaev V. G. et. al. (2010) Prospects of development of Renewable Power Sources (RES) in Russian Federation, The results of TACIS Project, Europe Aid/116951/C/SV/RU, Moscow: Atmograph. [16] Patriche C. V., (2009) Metode statistice aplicate in climatologie. Iaşi, Terra Nostra.

[17] Rich P., 2000, Solar Analyst 1.0. User Manual. Solar Environmental Modeling Institute, p. 51.

[18] Лассе Г. Ф. (1978) Климат Молдавской ССР (Clima în Moldova Republica Sovietică Socialistă), Л.: Гидрометеоиздат.

[19] Лассе Г. Ф. (1969) Микроклиматические наблюдения на территории совхоза «Семилетка» Кагульского района. В: сб. работ Кишиневской Гидрометеорологической Обсерватории (Observații microclimatice pe teritoriul satului „Semiletka” raionul Cahul, lucrări ale Observatorului Hidrometeorologic din Chișinău), Киев: Управление Гидрометеослужбы УССР, вып. 4 .
[20] Москалюк И. С. (1966) К вопросу разработки ветроэнергетического кадастра Молдавии (Си privire la dezvoltarea cadastrului energiei eoliene din Moldova), В: Тр. Кишиневского Сельскохозяйственного Института.

[21] *** Platforma plutitoare Sinn Power poate colecta simultan energia valurilor, vântului și soarelui, https://ecotechnica.com.ua/tag/volnovayaenergiya.html

[22] $* * * \quad \mathrm{http}: / /$ energomir.biz/alternativnayaenergetika/voda/energiya-prilivov-i-otlivov.html

[23] Ceban V., Dezvoltarea energiei regenerabile în Republica Moldova: realităţi, capacităţi, opțiuni, perspective, Asociația pentru politică externă. http://old.ape.md/public/publications/2144156_md_a neza_nr_2_vad.pdf

[24] *** Pericol: România va ajunge să importe masiv energie electrică în anii ce vin. Explicații, https://www.economica.net/pericol-romania-va-

ajunge-sa-importe-masiv-energie-electrica-in-anii-cevin-explica-ii_188065.html

[25] *** https://destepti.ro

[26] Hotărîre Nr. 958 din 21.08.2007, http://lex.justice.md/index. 